\title{
Potential of reduction in carbon dioxide equivalent emissions via energy efficiency for a textile factory
}

\author{
Aytaç Perihan Akan \\ Hacettepe University, Ankara, Turkey, aperihanakan@gmail.com, orcid.org/0000-0003-4626-4741 \\ Ahmet Erhan Akan \\ Namık Kemal University, Tekirdağ, Turkey, aeakan@nku.edu.tr, orcid.org/0000-0003-1806-7943
}

Arrived: 23.03.2018 Accepted: 07.05.2018 Published: 15.06.2018

\begin{abstract}
Today, one of the most important issues in the world is that the concentration of carbon dioxide in the atmosphere which is the fundamental reason for global warming exhibits a severe increase in every passing year. It is a general view that the most crucial step to succeed in mitigation carbon emissions is the reduction of energy consumption. In this study, production and energy consumption data only for year 2016 of an industrial textile factory in Turkey were employed to explore carbon emission mitigation potential through energy efficiency. The research consists of three steps listed as i) data collection, ii) data processing and iii) data evaluation. Energy saving potential of the industry has been determined with the help of the energy consumption relations developed depending on data obtained from the factory by calculating the target energy consumption for year 2017 and beyond. Also, the amount of reduction in carbon emissions stemming from the amount of fuel saved thanks to energy efficiency has been calculated. Energy saving potential for 2017 and later years was found 98.9 TOE per year and also due to these saving, the amount of the reduction in $\mathrm{CO}_{2}$ emissions of the factory will totally be 2.75 milliontones $\mathrm{CO}_{2}$ in comparison to year 2016. It is also seen that financial savings will be approximately $€ 28,646.06$ for the year 2017 and later years.
\end{abstract}

Keywords: Carbon dioxide equivalent emissions, Energy efficiency, Environmental aspects, Specific energy, Textile industry.

Cite this paper as:

Akan, AP, Akan AE. Potential of carbon footprint reduction via energy efficiency for a textile factory. Journal of Energy Systems 2018; 2: 57-69, DOI: 10.30521/jes.409148

(C) 2018 Published by peer-reviewed open access scientific journal, JES at DergiPark (www.dergipark.gov.tr/jes)

\begin{tabular}{r|l} 
Nomenclature & \\
\hline $\mathrm{CFP}$ & Carbon Footprint \\
$\mathrm{CFCs}$ & Chlorofluorocarbons \\
$\mathrm{CH}_{4}$ & Methane \\
$\mathrm{CO}_{2}$ & Carbon Dioxide \\
$\mathrm{CUSUM}$ & Cumulative Total Values \\
$\mathrm{GHG}$ & Greenhouse Gas \\
$\mathrm{GWP}$ & Global Warming Potential \\
$\mathrm{HFCs}$ & Hydrofluorocarbons \\
$\mathrm{H}_{2} \mathrm{O}$ & Water Vapor \\
$\mathrm{N}_{2} \mathrm{O}$ & Nitrous Oxide \\
$\mathrm{O}_{3}$ & Ozone \\
$\mathrm{PFCs}$ & Perfluorocarbons \\
$\mathrm{SEC}$ & Specific Energy Consumption \\
$\mathrm{SF}$ & Sulfur Hexafluoride \\
$\mathrm{TOE}$ & Tonne of Oil Equivalent \\
\hline
\end{tabular}




\section{INTRODUCTION}

Globally, carbon-based fuels are significantly used to generate energy that is heavily used in the industry is one of the most major expenditures of factories. Owing to the population growth and economic growth of countries, the consumption of energy has been showing a remarkable increase recently [1]. The relationship between energy consumption and economic growth, as well as economic growth and environmental pollution is a crucial topic these days [2]. As would be expected, the rapid expansion of energy production and consumption has resulted in various environmental problems at the local, regional and global levels [3]. Due to these reasons, efficient use of energy is unavoidable. Energy efficiency not only increases the competitive power of institutions, but also contributes greatly to reducing emissions released to the environment. Energy efficiency is one of the fastest and most economical ways to influence the environmental performance improvements of industrial institutions. It is inevitable to provide continuity, quality and low cost of energy inputs in industrial institutions where energy cost is high [4]. Hence, industrial institutions should have an energy management system that will increase productivity and profitability in the institutions by providing energy saving thanks to true energy-management [5]. It is known that the development and effectively implementation of an appropriate energy management program can lead to remarkable energy savings for the industrial organization. The energy management system is a disciplined work designed to make energy usage more efficient without any slowdown in production taking into account product quality, safety and all environmental conditions [6]. Improvements in energy efficiency have been suggested as both a measure of progress towards sustainable development and as a means of achieving sustainability. The popular interpretation of energy efficiency is 'doing more with less' that is of reducing the energy requirements associated with a given level of economic activity [7]. Many governmental plans to mitigate greenhouse gas (GHG) emissions involve improving energy efficiency in the home, in industry and in transportation. It can be easily expressed that the increase in energy efficiency can bring about the decrease in energy usage, thereby can be observed the mitigation in the GHG emissions. GHG can be identified as any gas in the atmosphere resulting in a greenhouse effect trapping thermal radiation from the sun in Earth's atmosphere. Carbon dioxide $\left(\mathrm{CO}_{2}\right)$, methane $\left(\mathrm{CH}_{4}\right)$, nitrous oxide $\left(\mathrm{N}_{2} \mathrm{O}\right)$, ozone $\left(\mathrm{O}_{3}\right)$, water vapor $\left(\mathrm{H}_{2} \mathrm{O}\right)$, and chlorofluorocarbons (CFCs) are the major GHSs in Earth's atmosphere [8; 9]. Among them $\mathrm{CO}_{2}$ emissions are considered as a dominant contributor to the greenhouse effect triggering global warming and climate change [10;11]. In recent years, a lot of scientific effort has been put to reduce $\mathrm{CO}_{2}$ emissions from energy production.

In the literature, Worrell and co-workers presented that a research about the relationship between costeffective energy efficiency and the reduction of $\mathrm{CO}_{2}$ emissions from iron and steel sector in USA. In the period 1958-1994, owing to the intensity of physical energy for iron and steel production fell from 35.6 $\mathrm{GJ} /$ tonne to $25.9 \mathrm{GJ} /$ tonne, $39 \%$ reduction in $\mathrm{CO}_{2}$ emissions was observed. Worrell et al., (2001) found that in 1994, $18 \%$ of the energy consumed for iron and steel production in USA could be decreased by energy efficiency, and thus a $19 \%$ reduction in $\mathrm{CO}_{2}$ emissions could be provided [12]. Perry and coworkers expressed that the improvements in energy efficiency in the industry equally contribute to the decrease of energy consumption and $\mathrm{CO}_{2}$ emissions. They developed Total Site targeting method being one of integrating energy systems. Perry et al., (2008) found that Total Site targeting method can be effectively applied to integrate renewables into the energy source mix and finally diminish the carbon footprint of these locally integrated energy sectors [1]. K1lic, (2017) investigated energy efficiency for a natural gas fueled boiler in a textile industry and measured mass and energy balance in boiler operating conditions and calculated boiler efficiency, potential energy saving areas, saving amounts, investment costs and payback periods by taking into account mass and energy balances [13]. Hanley and co-workers investigated the effect of improvements in energy efficiency both theoretically and empirically. They concluded that the increase in the energy efficiency leads to improvements in local sustainability indicators [7].

This study was implemented by benefiting energy consumption-production data in 2016 of a textile factory established in Çorlu, Turkey in 2000 . The annually production capacity of the factory is 700 
tonnes. The factory has yarn twisting, yarn dyeing, warp, weaving, embroidery, quality control and packaging processes. There are 15 machines in the yarn twisting section, 9 machines in the warp section, 57 machines in the weaving section, including 24 jacquards and 33 armor, and 4 machines in the embroidery section containing 3 standards and 1 pentacut. The annual capacity of yarn dyeing section is 700 tonnes and that of weaving section is $3,000,000 \mathrm{~m}$. The factory is working with the order method under its capacity and the number of machines used has been meeting the job. There are 1 natural gasfueled steam boiler and 1 coal-fueled steam boiler that will meet the steam and heat needs of the factory and the machines that will run the processes within the factory. There is an economizer, hot water boiler, condensate tank in the natural gas boiler operating at 5 bar operating pressure and one heat exchanger is used.

\section{METHOD}

\subsection{Energy Scanning}

In order to investigate energy efficiency in the factories, energy screening must first be done. In the energy screening, the production and consumption quantities of the factory are taken according to the specified time frame and converted into schedules. According to the schedules obtained, necessary calculations are made and energy analysis graphs are constituted. These graphics provide a comparison between consumption and production. Thus, the points at which the factory can save money can be determined. Then, savings that can be made with various calculation methods are calculated. The first stage of energy screening is the collection of energy and production data. First of all, data collection strategies need to be determined in the collection of data. For this purpose, the following process steps are applied [5];

a. Name of the production with energy types to collect data,

b. Determination of energy and production points to be measured,

c. Determination of measurement types (such as measuring instruments) and periods (at least 10-20 sets of data should be taken)

d. The measurement period (at least 10 weeks for weekly measurements, at least one year for monthly measurements) and the determination of the type and location of data collection.

\subsubsection{Determination of energy consumption standard}

Once data has been collected, the standard line for each operator's energy consumption should be determined. This standard line is a linear equation showing that energy requirement is dependent on specific variables (production, weather conditions, etc.). These equation types are divided into three [5].

ENERGY $=\mathrm{a}+\mathrm{bP}$ is a linear equation where; $\mathrm{a}$ and $\mathrm{b}$ are constant values, and $\mathrm{P}$ is a specific variable for section examined. The type of standard equation to be appropriate for any section depend on the number of specific variables and the relationship between energy and these variables. These equations are:

$$
\text { Type 1; } E=a
$$

Energy consumption is constant and there are no specific variables for the section examined. In this case, the energy consumption of the section examined is fixed at the beginning regardless of production.

$$
\text { Type 2; } E=a+b P
$$


Energy consumption depends on a single specific variable $\mathrm{P}$ (production). In this linear equation, a is the amount of energy that is not related to production.

$$
\text { Type } 3 ; E=a+b P 1+c P 2+d P 3+\cdots
$$

In this equation, energy consumption depends on more than one specific variable. These specific variables are P1, P2, P3, various variables like production amount, weather conditions etc. or a variety of types of products produced in the same section, where a is constant showing energy consumption that occurs when all the specific variables are zero and also being irrelevant to production. The values of $b$, $\mathrm{c}, \mathrm{d}$ constants depend on the importance of the relevant variables [14].

After the standard equation found, the targets are determined. While the standard is determined for each section, target must be also determined at the same time. The target is an equation in the same form with the standard. It is necessary to regularly compare expected energy use with actual energy consumption values to assess performance after the target has been determined in the factory. To do this, specific energy consumption (SEC) values can be employed. SEC is defined as the energy used per unit of product. SEC value is especially important for monitoring the effect of various operating conditions on factory production performance. The increase of SEC value indicates a decrease in performance and an unnecessary increase in energy consumption [5]. SEC method was used to evaluate the energy efficiency and performance of the factory. Specific variables such as production in a plant can be identified as 'tonne, $\mathrm{kg}, \mathrm{m}^{2}$, item' etc.

$$
\text { Specific Energy Consumption=(Total Energy Consumption }) /(\text { Total Production })
$$

As another assessment method, drawing cumulative total values (CUSUM) chart is also appropriate for viewing the status of a plant. An evaluation is made between production and energy data to draw CUSUM graph. For this, the standard equation is calculated by the least squares method. If there is no mathematical relation between the data, that is, if the standard equation does not lead us to logical results, the theoretical real consumption is calculated, depending on the target data set. A suitable CUSUM graph is drawn accordingly. When this graph is examined, the values with negative slope and the areas remaining in the negative region show when the plant has a good performance, and the positive ones show the times of worsening [15].

\subsection{Global Climate Change}

The concentration of atmospheric $\mathrm{CO}_{2}$ in the atmosphere has increased significantly from about 280 ppm in 1780 to 367 ppm in 1994 and to 410 ppm in April, 2018 [16; 17]. This increase of $\mathrm{CO}_{2}$ in the atmosphere includes both anthropogenic and natural emissions, i.e. volcanoes, fires [16]. When $\mathrm{CO}_{2}$ is released into the atmosphere, it traps heat much like the glass in a greenhouse. Excessive trapped heat can trigger changes in the Earth's climate over time, containing a rise in the global average surface temperatures. Of all of greenhouse gases, $\mathrm{CO}_{2}$ is the single largest contributor to the problem, accounting for $60 \%$ of the direct radiative forcing of all GHGs. At a global level, such changes result in warmer air and ocean temperatures, changes in rainfall patterns, an increased number and intensity of floods, droughts, hurricanes and other storms, widespread melting of ice and snow, and rise of average sea level - all of which directly or indirectly affect human and ecological systems [18].

Carbon footprint (CFP) has become a widely used term and concept in the public debate on responsibility and abatement action against the threat of global climate change [19]. The CFP typically considered the six GHGs including $\mathrm{CO}_{2}, \mathrm{CH}_{4}, \mathrm{~N}_{2} \mathrm{O}$, sulfurhexafluoride $\left(\mathrm{SF}_{6}\right.$ ), hydrofluorocarbons (HFCs), perfluorocarbons (PFCs) is the total amount of $\mathrm{CO}_{2}$ and other greenhouse gases, emitted over the full life cycle of a process or product. It is expressed as grams of $\mathrm{CO}_{2}$ equivalent per kilowatt hour of generation $\left(\mathrm{gCO}_{2} \mathrm{eq} / \mathrm{kWh}\right)$, which accounts for the different global warming effects of other greenhouse gases $[19 ; 9 ; 20]$. Global Warming Potential (GWP) is used as an indicator to quantify the CFP. According to GWP, CFP is calculated by following equation 
Climate Change $=\sum i G W P_{a, i} \times m_{i}$

Where, GWPa, i is the Global Warming Potential for substance $\mathrm{i}$ integrated over a specified number of years and $\mathrm{mi}(\mathrm{kg})$ is the quantity of substance $\mathrm{i}$ emitted. The indicator result is expressed in $\mathrm{kg}$ of the reference substance, $\mathrm{CO}_{2}[9]$.

New technologies are needed to mitigate $\mathrm{CO}_{2}$ emissions to combat with global climate change and in the present study, energy efficiency method is used to reduce $\mathrm{CO}_{2}$ emissions stemming from various sources that can be identified as the inputs of the factory namely coal, natural gas and electricity. The decrease in the amount of $\mathrm{CO}_{2}$ emissions depending on the decrease in the consumption of coal, natural gas as well as electricity thank to energy efficiency technique is presented in the results section.

\section{APPLICATION}

Electricity, natural gas and coal are used as energy source in the factory which is examined in this study. Energy scanning of the factory for the year 2016 was carried out. The types of energy consumed and their costs are presented in Table 1.

Table 1. Energy consumption and cost values for the textile factory.

\begin{tabular}{lrcrrrrrr}
\hline \multirow{2}{*}{ Fuel Type } & \multicolumn{4}{c}{ Consumption } & & \multicolumn{2}{c}{ Cost } & \multicolumn{2}{c}{ Unit Cost } \\
& \multicolumn{1}{c}{ Quantity } & Unit & \multicolumn{1}{c}{ TOE } & \% Total & Euro $(€)$ & $€ / \mathrm{kWh}$ & $\%$ Total & \multicolumn{1}{c}{ /TOE } \\
\hline Electricity & $833,865.00$ & $\mathrm{kWh}$ & 71.71 & 17.56 & $53,951.07$ & 0.0647 & 45.61 & 752.33 \\
Natural gas & $641,890.38$ & $\mathrm{kWh}$ & 55.20 & 13.52 & $14,594.56$ & 0.0239 & 12.34 & 264.38 \\
Coal & $3,270,968.43$ & $\mathrm{kWh}$ & 281.30 & 68.92 & $49,728.78$ & 0.0144 & 42.05 & 176.78 \\
Total & $4,746,723.81$ & $\mathrm{kWh}$ & 408.22 & 100.00 & $118,274.41$ & 0.0249 & 100.00 & $1,193.49$ \\
\hline
\end{tabular}

As seen in Table 1, $17.56 \%$ of the energy used in the textile factory is composed of electricity, $13.52 \%$ is natural gas and $68.92 \%$ is coal. Cost percentages of these sources for the factory are electricity with $45.61 \%$, natural gas with $12.34 \%$, coal with $42.05 \%$. Energy production and consumption values in terms of the types of fuel used in the textile factory are monthly presented for year 2016 in Table 2.

Table 2. Energy production and consumption values of the textile factory in the year 2016.

\begin{tabular}{|c|c|c|c|c|c|c|c|c|c|c|}
\hline $\begin{array}{c}\text { Fuel Type } \\
\text { and Cost } 2016\end{array}$ & $\begin{array}{c}\text { Electricity } \\
\text { Cons. } \\
(\mathrm{kWh})\end{array}$ & $\begin{array}{c}\text { Electricity } \\
\text { Cost } \\
(€)\end{array}$ & $\begin{array}{c}\text { Natural } \\
\text { Gas Cons. } \\
\left(\mathrm{Sm}^{3}\right)\end{array}$ & $\begin{array}{c}\text { Natural } \\
\text { Gas Cons. } \\
(\mathrm{kWh})\end{array}$ & $\begin{array}{c}\text { Natural } \\
\text { Gas Cost } \\
(€)\end{array}$ & $\begin{array}{c}\text { Coal } \\
\text { Cons. } \\
\text { (Tonne) }\end{array}$ & $\begin{array}{l}\text { Coal } \\
\text { Cons. } \\
(\mathrm{kWh})\end{array}$ & $\begin{array}{c}\text { Coal } \\
\text { Cost } \\
(€)\end{array}$ & TOE & $\begin{array}{c}\text { Production } \\
\text { (Tonne) }\end{array}$ \\
\hline JAN. & $65,775.00$ & $4,255.64$ & $16,361.00$ & $156,724.75$ & $3,563.43$ & 53.90 & $381,761.72$ & $5,803.95$ & 51.97 & 25.00 \\
\hline FEB. & $62,164.00$ & $4,022.01$ & $1,255.00$ & $12,021.85$ & 273.34 & 29.30 & $207,525.39$ & $3,155.02$ & 24.23 & 27.50 \\
\hline MAR. & $68,429.00$ & $4,427.36$ & $1,255.00$ & $12,021.85$ & 273.34 & 52.16 & $369,437.69$ & $5,616.59$ & 38.69 & 30.00 \\
\hline APR. & $64,345.00$ & $4,163.12$ & $5,678.00$ & $54,390.51$ & $1,236.67$ & 45.70 & $323,682.94$ & $4,920.98$ & 38.05 & 31.00 \\
\hline MAY & $74,876.00$ & $4,844.48$ & $3,034.00$ & $29,063.19$ & 660.81 & 29.52 & $209,083.60$ & $3,178.71$ & 26.92 & 35.00 \\
\hline JUNE & $65,887.00$ & $4,262.89$ & $2,806.00$ & $26,879.14$ & 611.15 & 50.24 & $355,838.76$ & $5,409.84$ & 38.58 & 34.00 \\
\hline JULY & $71,007.00$ & $4,594.15$ & $3,649.00$ & $34,954.38$ & 794.75 & 26.52 & $187,835.27$ & $2,855.67$ & 25.27 & 38.00 \\
\hline AUG. & $86,272.00$ & $5,581.80$ & $7,931.00$ & $75,972.37$ & $1,727.37$ & 21.08 & $149,304.96$ & $2,269.89$ & 26.79 & 36.00 \\
\hline SEPT. & $63,073.00$ & $4,080.82$ & $1,255.00$ & $12,021.85$ & 273.34 & 22.04 & $156,104.42$ & $2,373.27$ & 19.88 & 39.00 \\
\hline OCT. & $71,721.00$ & $4,640.35$ & $1,255.00$ & $12,021.85$ & 273.34 & 25.26 & $178,910.97$ & $2,720.00$ & 22.59 & 38.00 \\
\hline NOV. & $71,173.00$ & $4,604.89$ & $1,597.00$ & $15,297.93$ & 347.83 & 52.90 & $374,678.94$ & $5,696.27$ & 39.66 & 31.00 \\
\hline DEC. & $69,143.00$ & $4,473.55$ & $20,933.00$ & $200,520.70$ & $4,559.21$ & 53.20 & $376,803.78$ & $5,728.58$ & 55.60 & 33.50 \\
\hline TOTAL & $833,865.00$ & $53,951.07$ & $67,009.00$ & $641,890.38$ & $14,594.56$ & 461.82 & $3,270,968.43$ & $49,728.78$ & 408.22 & 398.00 \\
\hline
\end{tabular}

Monthly change of fuel consumption used in the factory is presented in Figure 1. 


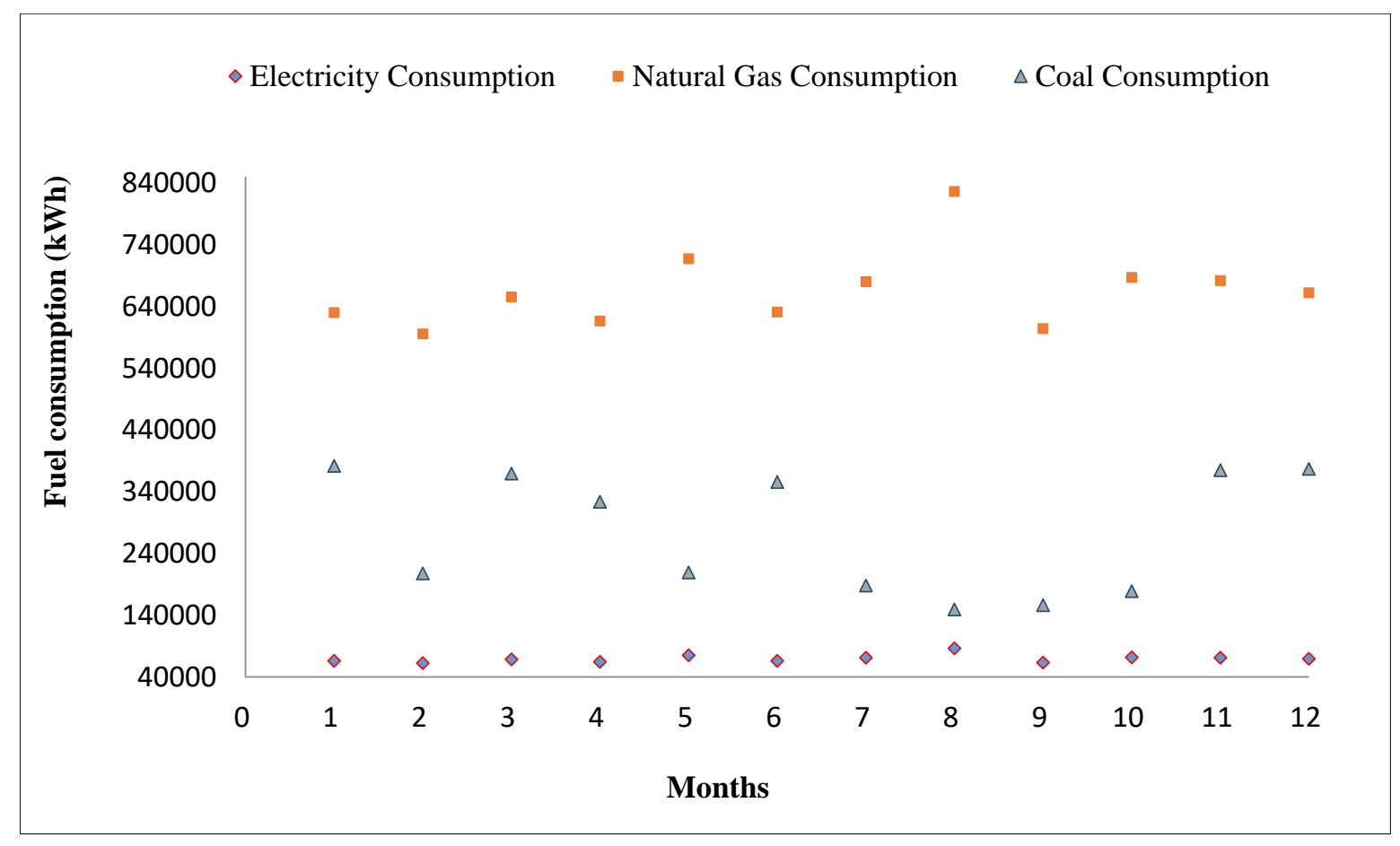

Figure 1. Fuel type - month consumption chart.

According to Figure 1, when monthly consumption amounts are analyzed according to the type of fuel, it is seen that electricity consumption exhibits a more stable graphic due to the constant energy consumed by the machines that will realize the processes compared to natural gas and coal consumption.

Table 3. SEC values for the year 2016.

\begin{tabular}{rrrr}
\hline ENERGY & TOE & Production $(\mathrm{kg})$ & SEC $(\mathrm{TOE} / \mathrm{kg})$ \\
\hline JAN. & 51.97 & 25,000 & 0.00208 \\
FEB. & 24.23 & 27,500 & 0.00088 \\
MAR. & 38.69 & 30,000 & 0.00129 \\
APR. & 38.05 & 31,000 & 0.00123 \\
MAY & 26.92 & 35,000 & 0.00077 \\
2016 JUNE & 38.58 & 34,000 & 0.00113 \\
JULY & 25.27 & 38,000 & 0.00066 \\
AUG. & 26.79 & 36,000 & 0.00074 \\
SEPT. & 19.88 & 39,000 & 0.00051 \\
OCT. & 22.59 & 38,000 & 0.00059 \\
NOV. & 39.66 & 31,000 & 0.00128 \\
DEC. & 55.60 & 33,500 & 0.00166 \\
TOTAL & 408.2 & 398,000 & 0.00103 \\
\hline
\end{tabular}

The amount of production and specific energy consumption value (Eq.5) vs the total amount of energy consumed that is the amount of energy consumed per unit of production is monthly presented in Table 3 for year 2016. Graph showing monthly production-energy consumption values of the factory is exhibited in Figure 2.

According to Figure 2, The decrease in the SEC value indicates an increase in productivity. In this context, the most productive time of the factory was determined as September, while its most inefficient time was January. 


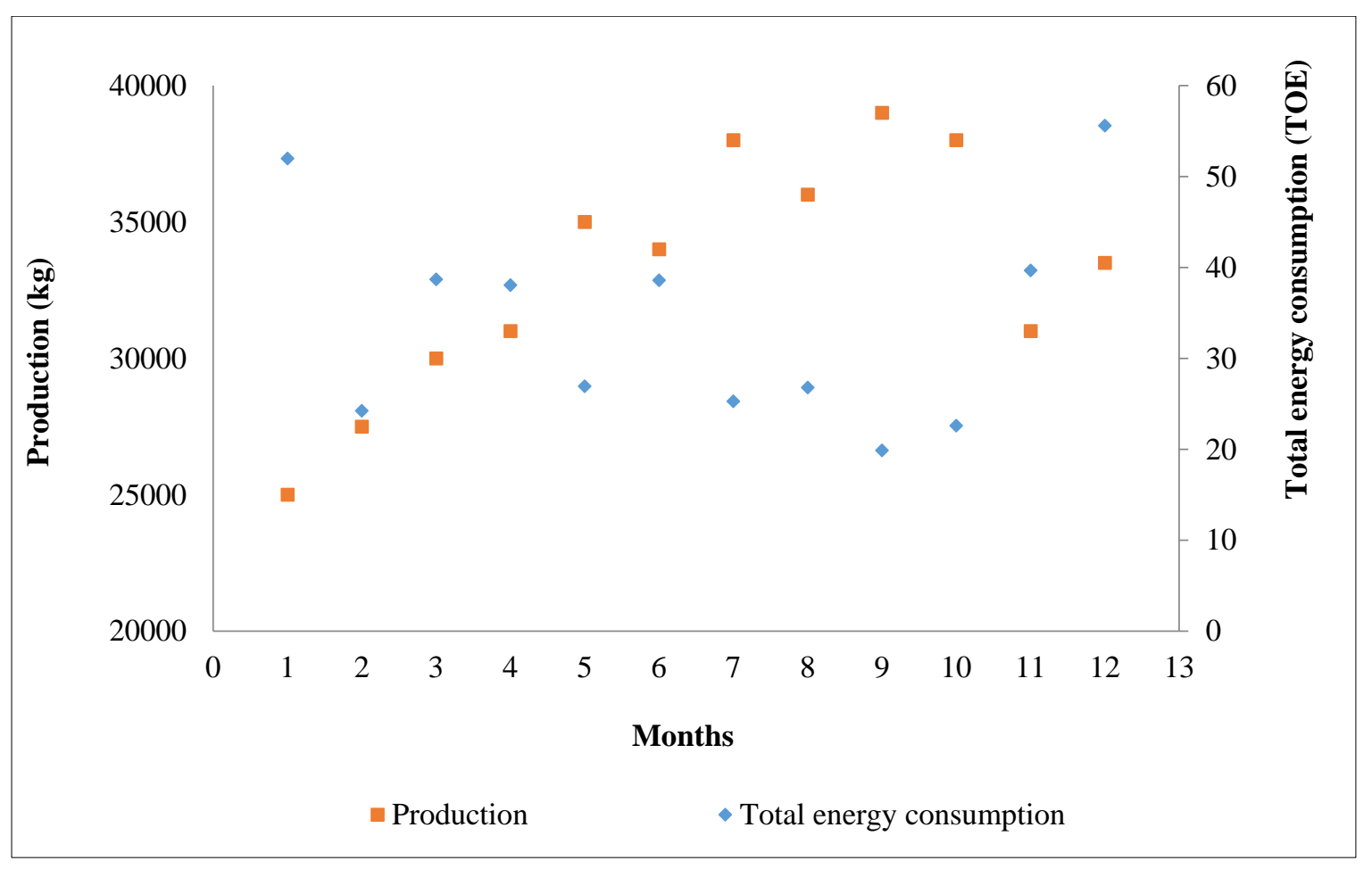

Figure 2. Graph for production- energy consumption of textile factory.

\section{RESULTS}

In this study, the potential for energy efficiency and the potential of the reduction in carbon dioxide equivalent emissions of the factory were investigated by evaluating the energy consumption-production data of the factory in Çorlu, Turkey.

\subsection{Energy Efficiency Research}

The energy consumption and production values of the factory in year 2016 are presented in Table 2. In the determination of the target consumption values for the year 2017, the energy consumption values of the year 2016 were evaluated by using the best performance based moon method. According to this evaluation, a graph was created between energy consumption and production and a standard equation was sought by using the production and consumption values of the factory in 2016 . The points below line graph obtained demonstrated the improvement of the efficiency in energy use. The goal here was to move down the line of linear SEC values by reducing the energy consumption per unit product (SEC). Then, the target SEC value equation was reached by reevaluating the points under the standard line. Standard and target equations are presented in Figure 3. 


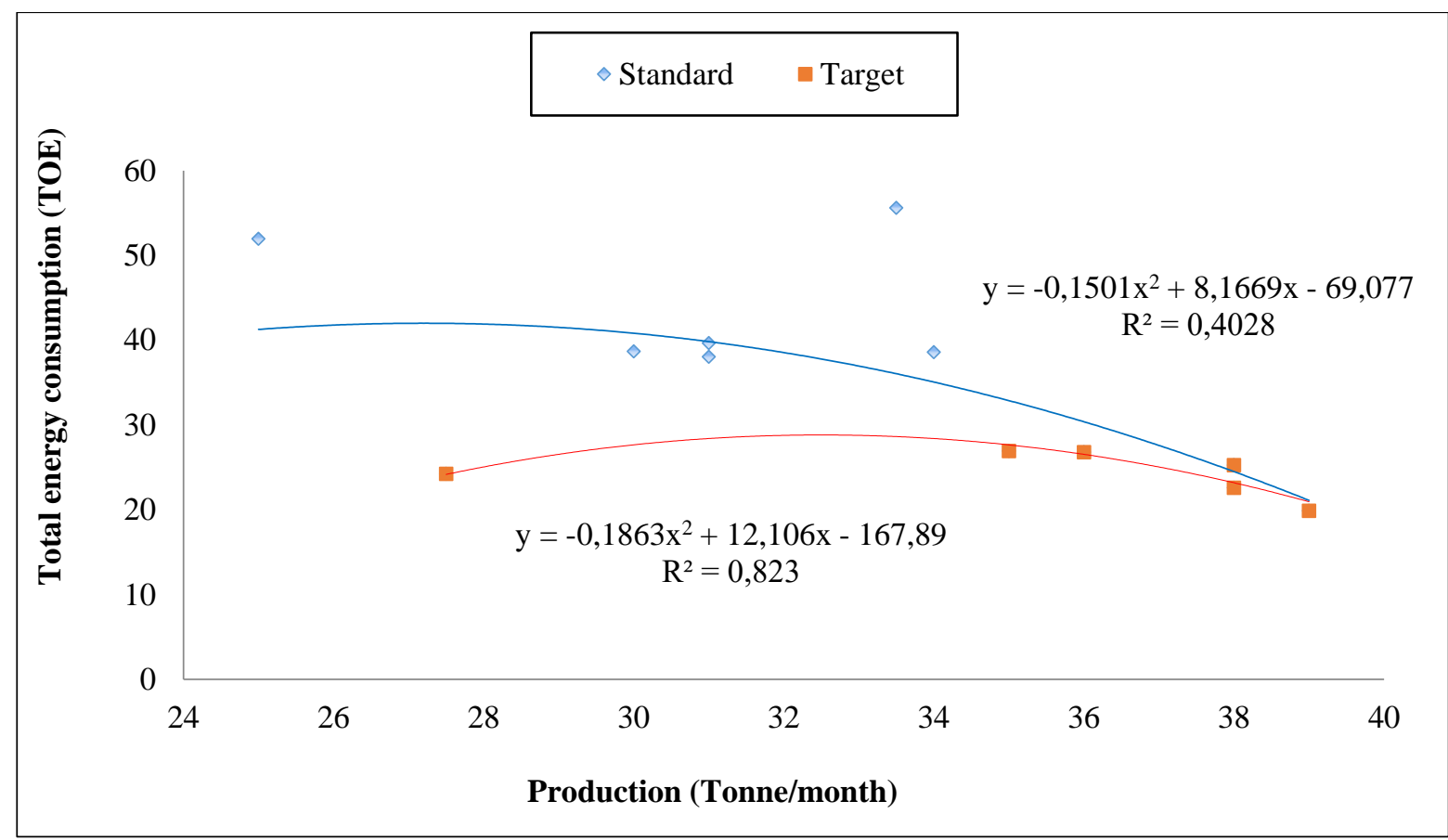

Figure 3. Graph for standard and target equations.

As shown in Figure 3, the standard (consumption) and target (for 2017 and later years) consumption graphs were drawn with the help of production-energy consumption data of the factory and the equations of these curves were determined. When these equations are examined, it can be easily said that they exhibit a convenience with the Type 3 equation given in Equation 3. The R coefficient calculated for the equations expresses the linear relation between production and consumption. When the relation between these equations was examined, polynomials were obtained. The points below the standard curve exhibit the consumption with the best productivity. The points under the consumption curve were reevaluated and relationship among them was examined as well as target line was reached by drawing a new curve with regression analysis. Equations found is given below for standard and target curves, respectively. Found equations is given below for standard and targeted curves respectively.

$$
y_{\text {standard }}=-0,1501 \times 2+8,1669 x-69,077
$$

$$
y_{\text {target }}=-0,1863 x^{2}+12,106 x-167,86
$$

According to the standard consumption graph, $\mathrm{R}^{2}$ value was 0.4028 and $\mathrm{R}^{2}$ value according to the target consumption graph was found as 0.823 . Once the square root of $\mathrm{R}^{2}$ value in the graph of productiontotal energy consumption will be near to 1 value, the more linear the production-consumption relation will occur. According to the actual working conditions of the factory, the R value is 0.63 and the target $\mathrm{R}$ value is 0.91 , indicating that the linear relationship between energy consumption and production gets better. Thus, it can be accepted that $91 \%$ of the change in energy consumption per product can be explained. In equations, $\mathrm{y}$ indicates consumption and $\mathrm{x}$ is production. The target energy consumption values are the energy consumptions calculated according to target equation (Eq. 7). By comparing the standard, target energy consumption and SEC values, energy saving potential of the factory was determined. These calculated values are presented in Table 4. Target energy saving is the difference between standard total energy consumption and target total energy consumption. 
Table 4. Production, Energy Consumption and SEC values.

\begin{tabular}{crrrrrr}
\hline ENERGY & Production & $\begin{array}{c}\text { Standard Total } \\
\text { Energy } \\
\text { Consumption }\end{array}$ & $\begin{array}{c}\text { Standard } \\
\text { SEC }\end{array}$ & $\begin{array}{c}\text { Target Total } \\
\text { Energy } \\
\text { Consumption }\end{array}$ & Target SEC & $\begin{array}{c}\text { Target Energy } \\
\text { Saving }\end{array}$ \\
\cline { 2 - 7 } (Tonne/Month) & (TOE/Month) & (TOE/Tonne) & (TOE/Month) & (TOE/Tonne) & (TOE/Month) \\
\hline JAN. & 25.00 & 51.97 & 2.0788 & 18.54 & 0.74 & 33.4 \\
FEB. & 27.50 & 24.23 & 0.88109 & 24.39 & 0.89 & -0.160 \\
MAR. & 30.00 & 38.69 & 1.2897 & 27.92 & 0.93 & 10.8 \\
APR. & 31.00 & 38.05 & 1.2274 & 28.68 & 0.93 & 9.37 \\
MAY & 35.00 & 26.92 & 0.76914 & 28.00 & 0.80 & -1.08 \\
JUNE & 34.00 & 38.58 & 1.1347 & 28.73 & 0.84 & 9.85 \\
JULY & 38.00 & 25.27 & 0.66500 & 23.58 & 0.62 & 1.69 \\
AUG. & 36.00 & 26.79 & 0.74417 & 26.90 & 0.75 & -0.110 \\
SEPT. & 39.00 & 19.88 & 0.50974 & 21.37 & 0.55 & -1.490 \\
OCT. & 38.00 & 22.59 & 0.59447 & 23.58 & 0.62 & -0.990 \\
NOV. & 31.00 & 39.66 & 1.2794 & 28.68 & 0.93 & 10.9 \\
DEC. & 33.50 & 55.60 & 1.6597 & 28.95 & 0.86 & 26.7 \\
TOTAL & 398.0 & 408.2 & 12.833 & 309.3 & 9.5 & 98.91 \\
\hline
\end{tabular}

It was determined that the standard SEC values of the year 2016 were changed between 0.51 and 2.08 TOE/tonne, while the target SET values were between 0.55 and $0.93 \mathrm{TOE} /$ tonne. Standard SEC and target SEC values versus production are exhibited in Figure 4.

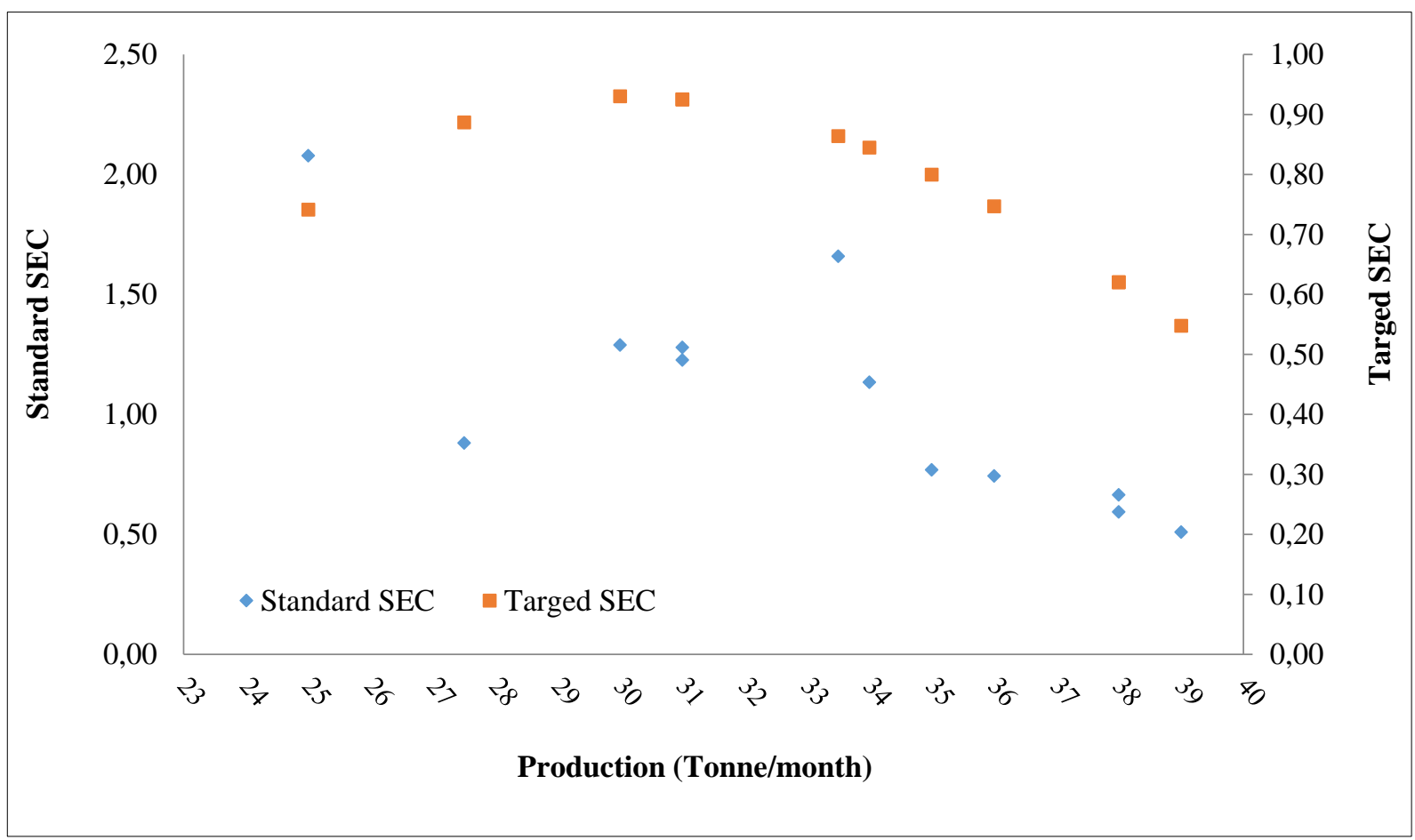

Figure 4. Standard - Target SEC and production chart.

Energy-saving potential for the factory, can also be calculated by plotting the cumulative total values (CUSUM). To draw CUSUM graph, the difference between the standard energy consumption values of the year 2016 and target (theoretical) energy consumption values was found. Then, cumulative total values were calculated. 
Table 5. Cumulative total values (CUSUM)

\begin{tabular}{crrrrr}
\hline & Production & $\begin{array}{c}\text { Standard Energy } \\
\text { Consumption }\end{array}$ & $\begin{array}{c}\text { Theoretical Energy } \\
\text { Consumption }\end{array}$ & Difference & $\begin{array}{c}\text { Accumulative Energy } \\
\text { Difference }\end{array}$ \\
\cline { 2 - 6 } & (Tonne/Month) & (TOE/Month) & (TOE/Month) & (TOE) & $\begin{array}{c}\text { (TOE/accumulated } \\
\text { months) }\end{array}$ \\
\hline JAN. & 25.00 & 51.97 & 18.54 & -33.43 & -33.43 \\
FEB. & 27.50 & 24.23 & 24.39 & 0.1600 & -33.27 \\
MAR. & 30.00 & 38.69 & 27.92 & $-10,77$ & -44.04 \\
APR. & 31.00 & 38.05 & 28.68 & -9.370 & -53.41 \\
MAY & 35.00 & 26.92 & 28.00 & 1.080 & -52.33 \\
JUNE & 34.00 & 38.58 & 28.73 & -9.850 & -62.18 \\
JULY & 38.00 & 25.27 & 23.58 & -1.690 & -63.87 \\
AUG. & 36.00 & 26.79 & 26.90 & 0.1100 & -63.76 \\
SEPT. & 39.00 & 19.88 & 21.37 & 1.490 & -62.27 \\
OCT. & 38.00 & 22.59 & 23.58 & 0.9900 & -61.28 \\
NOV. & 31.00 & 39.66 & 28.68 & -10.98 & -72.26 \\
DEC. & 33.50 & 55.60 & 28.95 & -26.65 & -98.91 \\
TOTAL & 398.0 & 408.2 & 309.3 & -98.91 & -98.91 \\
\hline
\end{tabular}

Accumulative sum of the factory are given in Table 5. The energy consumption graph of the cumulative energy consumption data calculated according to this table is shown in Figure 5.

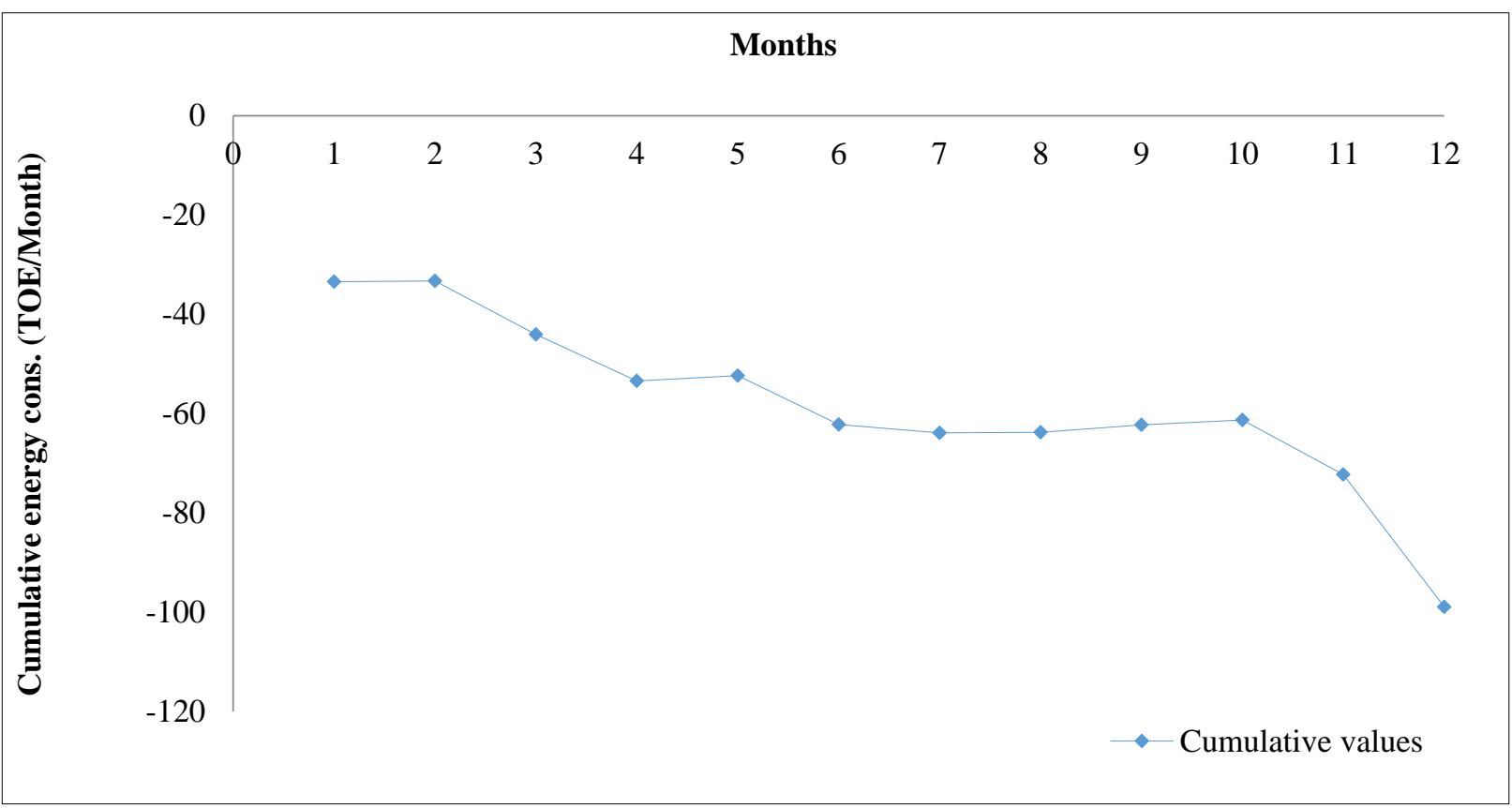

Figure 5. Cumulative total values.

In the result of the calculations made by using the energy production and consumption data of the year 2016 by both methods, the theoretical energy saving potential of the factory for the year 2017 and the following years was found as $24,22 \%$ (Table 4-5) and 98,9 TOE per year, thus $28,646.06 €$ annual financial savings will be provided. When the energy consumption ratios of the factory according to fuel type are examined, electricity consumption is determined as $17.56 \%$, natural gas consumption as 13.52 $\%$ and coal consumption as $68.92 \%$. If the factory can provide energy savings of $24.22 \%$ for the year 2017 and it is assumed that the savings are distributed proportionally among the energy sources used as shown in Table 6. 
Table 6. Energy savings in 2017

\begin{tabular}{llll}
\hline If reduction is $24.22 \%$ & 2016 & 2017 & Saving \\
\hline Electricity $[\mathrm{kWh}]$ & $833,865.00$ & $631,902.90$ & $201,962.10$ \\
Natural Gas $\left[\mathrm{Sm}^{3}\right.$ ] & $67,009.00$ & $50,779.42$ & $16,229.58$ \\
Coal [Tonnes] & 461.82 & 349.97 & 111.85 \\
\hline
\end{tabular}

The studies to be done in order to realize the energy saving potential shown in Table 6 in the factory is shown below:

First of all, it is necessary to evaluate the boiler system which consumes the energy most intensively and to evaluate the energy consuming systems separately.

The efficiency of natural gas boiler operating at 5 bar operating pressure can be made more efficient by means of a recuperator. In the recuperator, when the combustion air is heated by the flue gas, the flue gas temperature values will decrease and the boiler efficiency will increase.

Significant contribution to the energy potential will be achieved by the control of the insulation of boiler, collectors and faucets used throughout the line, and also by removing uninsulated or deformed parts.

In order to reduce the consumption of electric energy, which has a low share in the general energy consumption of the factory, energy consumption will be reduced by making the elements such as circulating pumps, electric motors, etc. frequency controlled and replacing the elements used in lighting with LED equivalents.

If the heating system is supported by renewable energy sources such as solar energy, it will come down to both the energy consumption values and the amount of carbon emissions emitted to the environment.

\subsection{Carbon Dioxide Equivalent Emissions}

Energy efficiency is one of the most promising approaches to minimize the carbon emissions stemming from industrial applications. The amount of $\mathrm{CO}_{2}$ emissions from the factory was determined in accordance with the equation taking place in the Intergovernmental Panel on Climate Change [21]. GHG emissions from stationary combustion have been found with the equation given below:

$$
\text { Emissions }_{G H G}(E)=\text { Fuel Consumption }(F C) \times \text { Emission Factor }(E F)
$$

Where $\mathrm{E}$ is the emission of a given GHG by type of fuel ( $\mathrm{kg} \mathrm{GHG),} \mathrm{FC} \mathrm{is} \mathrm{amount} \mathrm{of} \mathrm{fuel} \mathrm{combusted}$ (TJ) and EF is default emission factor GHG by type of fuel (kg gas/TJ). Emission factor values were taken as 56,100 $\mathrm{kgCO}_{2} / \mathrm{TJ}$ for natural gas and 94,600 $\mathrm{kg} \mathrm{CO}_{2} / \mathrm{TJ}$ for coal coke, respectively [21]. Furthermore, emission factor for electricity consumed can be accepted as $1.0097 \mathrm{kgCO}_{2} / \mathrm{kWh}$ [22]. In this study, $\mathrm{CO}_{2}$ emissions come from coal and natural gas used in the boiler and electricity being the main energy sources in the factory. Hence, in the determination of the ratio of the reduction in $\mathrm{CO}_{2}$ emissions via energy efficiency method is only considered to three main energy inputs of the factory.

In 2016, GHG emission values stemming from total fuel consumption for natural gas and coal as well as electricity were found as $0.1296,11.139$ and 0.0841 million-tonnes $\mathrm{CO}_{2}$, respectively. Moreover, thanks to energy efficiency in the factory that is the major step of this study, the decline in natural gas, coal and electricity consumption is presented in Table 7. 
Table 7. Carbon dioxide emissions in 2016 and in 2017

\begin{tabular}{lccc}
\hline \multirow{2}{*}{ If reduction is $24.22 \%$} & $\mathrm{CO}_{2}$ Emissions million-tonnes $\mathrm{CO}_{2}$ & Reduction million-tonnes $\mathrm{CO}_{2}$ \\
& 2016 & 2017 & \\
\hline Electricity & 0.0841 & 0.0638 & 0.0203 \\
Natural Gas & 0.1296 & 0.0982 & 0.0314 \\
Coal & 11.14 & 8.442 & 2.698 \\
\hline
\end{tabular}

According to Table 7, the amount of the decrease in $\mathrm{CO}_{2}$ emissions in the factory in 2017 will totally be 2.75 million-tonnes $\mathrm{CO}_{2}$ via the application of the energy efficiency in comparison to 2016.

\section{CONCLUSIONS}

In this study; a textile factory operating in Çorlu, Tekirdağ was examined in terms of energy efficiency potential and carbon footprint reduction of the factory according to the energy consumption-production data of the year 2016 and proposals were presented to provide the energy saving for year 2017 and afterwards. Major results of the study were listed in the following:

According to the present study, it was determined that the energy saving potential for year 2017 and thereafter is $24.22 \%$.

In the case of this saving, the reduction in the energy resources consumed by the factory is determined as 98.9 TOE. In this case, it is determined that an annual saving of $28,646.06 €$ will be obtained.

The amount of reduction in the carbon emissions in 2017 will be 2.75 million-tones $\mathrm{CO}_{2}$ thanks to the energy to be saved according to the consumption rates of the energy sources used in the factory.

\section{REFERENCES}

[1] Perry S, Klemes J, Bulatov I. Integrating Waste and Renewable Energy to Reduce the Carbon Footprint of Locally Integrated $\quad$ Energy $\quad$ Sectors, $\quad$ Energy $\quad 2008 ; \quad 33: 1489-1497$. <https://doi.org/10.1016/j.energy.2008.03.008>

[2] Acaravci A, Ozturk I. On the Relationship between Energy Consumption, $\mathrm{CO}_{2}$ Emissions and Economic Growth in Europe, Energy 2010; 35:5412-5420. <https://doi.org/10.1016/j.energy.2010.07.009>

[3] Kaygusuz K. Energy and Environmental Issues Relating to Greenhouse Gas Emissions for Sustainable Development in Turkey, Renewable and Sustainable Energy Reviews 2009;13:253-270. < https://doi.org/10.1016/j.rser.2007.07.009>

[4] Özdabak A, Ertem ME. Energy Management Techniques, Erdemir Steel-Iron Factory, Karabük, Turkey: Nokta Ofset Publishing, 2001.

[5] Söğüt Z, Oktay Z. The Effect on Energy Efficiency of Energy Scanning in the Industrial Sector and an Application, University of Dumlupınar, Journal of Graduate School of Science and Engineering. 2016; 10:151-162.

[6] Çakal E. An Investigation on Energy Management in Manufacturing of Agricultural Machineries, MSc, Trakya Universty, Edirne, Turkey, 2006.

[7] Hanley N, Mcgregor P, Swales JK, Turner K. Do Increases in Energy Efficiency Improve Environmental Quality and Sustainability Ecological Economics, 2009;68(3): 692-709. DOI: 10.1016/j.ecolecon.2008.06.004.

[8] Brewer RS. Literature Review on Carbon Footprint Collection and Analysis, CSDL Technical Report No. 2009;09-05, University of Hawai, Honolulu, USA.

[9] Muthu SS, Li Y, Hu JY, Ze L. Carbon Footprint Reduction in the Textile Process Chain: Recycling of Textile Materials, Fibers and Polymers 2012;13: 1065-1070. DOI 10.1007/s12221-012-1065-0.

[10] Soytas U, Sari R, Ewing BT. Energy Consumption, Income, and Carbon Emissions in The United States, Ecological Economics, 2007;62: 482-489. <https://doi.org/10.1016/j.ecolecon.2006.07.009>

[11] Ozturk I, Acaravci A. $\mathrm{CO}_{2}$ Emission, Energy Consumption and Economic Growth in Turkey, Renewable and Sustainable Energy Reviews, 2010;14: 3220-3225. <https://doi.org/10.1016/j.rser.2010.07.005> 
[12] Worrell E, Price L, Martin N. Energy Efficiency and Carbon Dioxide Emissions Reduction Opportunities in The US Iron and Steel Sector, Energy 2001;26: 513-536. < https://doi.org/10.1016/S0360-5442(01)000172>

[13] Kılıç Çanka F. Energy Efficiency and Emission Reduction Oppurtunities in the Industrial Boilers, Gazi University, Journal of Science Part C, 2017;5: 147-158.

[14] Kedici Ö. The Formation of Energy Management System in Turk Industry and Legislation of Energy Efficiency in the Industry, $3^{\text {rd }}$ National Plumbing Engineering Congress, 1997.

[15] Kedici Ö. Energy Management, Ministry of Energy and Natural Sources, Republic of Turkey, General Directorate of Renewable Energy, 1993.

[16] Luis P, Gerven TV, Bruggen BV. Recent Developments in membrane-based technologies for $\mathrm{CO}_{2} \mathrm{Capture}_{\text {, }}$ Progress in Energy and Combustion Science, 2012; 38: 419-448. <https://doi.org/10.1016/j.pecs.2012.01.004>

[17] NOAA Earth System Research Laboratory, Global Monitoring Division, Trend in Atmospheric Carbon Dioxide, https://www.esrl.noaa.gov/gmd/ccgg/trends/, Access in May 2018.

[18] Asia-Pacific Economic Cooperation (APEC) Publications, Building Capacity for $\mathrm{CO}_{2}$ Capture and Storage in the APEC Region, SOM Steering Committee on Economic and Technical Cooperation (SCE), Energy Working Group (EWG) Publishers, 2009. https://www.apec.org/Publications/2009/11/Building-Capacityfor-CO2-Capture-and-Storage-in-the-APEC-region-A-training-manual-for-policy-makers, Access in May 2018.

[19] Wiedmann T, Minx J. A Definition of Carbon Footprint, In: Ecological Economics Research Trends (Ed. C. C. Pertsova), Nova Science Publishers, 2007, pp. 1-11. ISBN 1-60021-941-1.

[20] Laurent A, Olsen SI, Hauschild MZ. Carbon Footprint as Environmental Performance indicator for the Manufacturing Industry, CIRP Annals, 2010;59: 37-40. https://doi.org/10.1016/j.cirp.2010.03.008.

[21] IPCC (Intergovernmental Panel on Climate Change), IPCC Guidelines for National Greenhouse Gas Inventories, http://www.ipcc-nggip.iges.or.jp/public/2006gl/vol2.html, Access in May 2018.

[22] Brander M, Sood A, Wylie C, Haughton A, Lovell J. Electricity-Specific Emission Factors for Grid Electricity, https://ecometrica.com/assets/Electricity-specific-emission-factors-for-grid-electricity.pdf. Access in May 2018. 